\title{
Synthesis and SAR Studies of New Oxadiazole-2-oxide Derivatives with Remarkable In Vitro Activity against Schistosoma japonicum \\ C M A Gause $\mathbf{M}^{1}$, Wen-Hua $\mathrm{F}^{1}$, Li-Jun $\mathrm{S}^{2}$, Chuan-Xin $\mathrm{Y}^{2^{*}}$ and Bainian $\mathrm{F}^{\mathbf{1}^{*}}$ \\ ${ }^{1}$ School of Pharmaceutical Science, Jiangnan University, Wuxi 214122, China \\ ${ }^{2}$ Key Laboratory on Technology for Parasitic Disease Prevention and Control, Ministry of Health, Jiangsu Institute of Parasitic Diseases, Wuxi 214064, China
}

\begin{abstract}
Schistosomiasis is the most neglected tropical disease in the world now where every day more and more people are being affected. The only approved drug Praziquantel (PZQ) that could not prevent re-infection but only effective against adult worms. Resistance of PZQ has been found in some areas, so an alternative drug would be needed as a substitute. Oxadiazole-2-oxide has been proven as potential anti schistosomal agents in which they kill both adult and juvenile worms. We synthesized 25 novel oxadiazole-2-oxide analogues and check their in vitro activity on adult Schistosoma japonicum. In here, all of them showed better in vitro activity than praziquantel and 1, 2, 5-oxadiazole2-oxide. Compounds 16, 17, 20, 23 and 24 showed excellent activity even in low concentration and short time period. There are no differences found while checking their in vitro activity against male and female worms. Some new functional groups would be synthesized here may lead us to the new treatment of schistosomiasis. The synthesis and structure activity relationship (SAR) studies of oxadiazole-2-oxide analogues with activity against $S$. japonicum can help us to design some more new derivatives to find out better activity and potential candidate. Some of these compounds could be used to develop new anti-schistosomal drugs while the mechanism of these compounds still needs to found.
\end{abstract}

Keywords: Schistosoma japonicum; Oxadiazole-2-oxide analogues; Antischistosomal activity; Neglected tropical disease

\section{Abbreviations}

DIBAl-H: Diisobutylaluminium Hydride; TGR: Thioredoxin Glutathione Reductase; SjTGR: S. japonicum Thioredoxin Glutathione Reductase; THF: Tetrahydrofuran; n-BuLi: n-Butyllithium; $\mathrm{PPh}_{3}$ : Triphenylphosphine; DMSO: Dimethyl Sulphoxide; PZQ: Praziquantel; NO: Nitric Oxide; SAR: Structure-activity Relationship

\section{Introduction}

Schistosomiasis (also known as bilharzia) is a vector-borne parasitic disease caused by trematode flatworms of the genus Schistosoma. It has affected more than 250 million people all over the world [1,2]. It is still a neglected tropical disease because of various control effects did not work well. Mostly, three species are responsible for particular relevance; Schistosoma mansoni, which is endemic in Africa, the Arabian Peninsula, South America and the Caribbean, Schistosoma haematobium, which occurs in Africa and the Arabian Peninsula, and Schistosoma japonicum, which is only restricted to China, the Philippines and Indonesia [3,4]. The only World Health Organization (WHO) recognized drug Praziquantel (PZQ) cannot stop reinfection and doesn't work against juvenile schistosomiasis [5]. However, the mechanism of action of PZQ is still unidentified although data shown it causes schistosomes to develop tetanic contractions and tegumental vacuoles; affected worms lose their hold on the vein wall, and then washed upstream to the liver and die [6-8]. Several PZQ-resistant isolates already have identified $[9,10]$. There have been several studies to modify PZQ, but have yet to reach clinical trials [11]. So, there are needs of new targets and drugs those can work both in adult and juvenile schistosomiasis. 1,2,5-Oxadiazole-2-oxide was identified by a group of scientist as new drug leads against Schistosoma japonica as well as other species, where thioredoxin glutathione reductase (TGR) showed new potential molecular target $[5,12]$. Before, it was believed that oxadiazole-2-oxide activity depends on NO production but later find out, there might be other targets and mechanisms than NO production or inhibition of SjTGR activity $[12,13]$.
As a preventive drug, praziquantel is not useful at all [14]. It also shows some side effects such as dizziness, rash, nausea, abdominal pain, pruritus, headache and drowsiness which could be connected with the result of worm death than the drug itself $[15,16]$. The shortcoming of PZQ is the circumstance that it is not active against juvenile schistosomes $[17,18]$. Oxamniquine is an aminoethyltetrahydroquinolone derivative, which is effective only against $S$. mansoni, generally the adult worms, and male worms are more sensitive to the drug [19]. However, a combination therapy for acute $S$. japonicum has failed to improved treatment efficacy compared with PZQ alone [20]. World Health Organization (WHO) approved six vaccine candidates until now which are still in trial phase [21]. There is an urgent need for integrated control programs and preventive chemotherapy. Therefore, we became interested in the synthesis of oxadiazole-2-oxide analogues to find out some new potential antischistosomal agents. We designed and synthesis some novel oxadiazole-2-oxide to target Schistosoma japonicum, where they have good killing activity. It did not inhibit the activity of SjTGR, so we found some new functional groups. Amine functional group could be a new lead of drug for treatment of Schistosoma japonicum, where the halogen contains oxadiazole-2-oxide showed good killing activity. These could be a new drug leads for the treatment and control

*Corresponding authors: Bainian F, School of Pharmaceutical Science, Jiangnan University, Wuxi 214122, China, E-mail: fengbainian@jiangnan.edu.cn

Chuan-Xin Y, Key Laboratory on Technology for Parasitic Disease Prevention and Control, Ministry of Health, Jiangsu Institute of Parasitic Diseases, Wuxi 214064, China, E-mail: chxnyu@163.com

Received January 16, 2017; Accepted February 01, 2017; Published February 08, 2017

Citation: C M A Gause M, Wen-Hua F, Li-Jun S, Chuan-Xin Y, Bainian F (2017) Synthesis and SAR Studies of New Oxadiazole-2-oxide Derivatives with Remarkable In Vitro Activity against Schistosoma japonicum. J Microb Biochem Technol 9: 535-543. doi: 10.4172/1948-5948.1000339

Copyright: $\odot 2017$ Gause M, et al. This is an open-access article distributed under the terms of the Creative Commons Attribution License, which permits unrestricted use, distribution, and reproduction in any medium, provided the original author and source are credited. 
of schistosomiasis. In here, we checked the in vitro activity against Schistosoma japonicum; maybe it will have effect other species too.

\section{Materials and Methods}

\section{Experimental}

Chemistry: All the chemicals were reagent grade and used as purchased. Some chemicals were stored in the laboratory as per chemical indication. ${ }^{1} \mathrm{H}-\mathrm{NMR}$ spectra $(400 \mathrm{MHz})$ were recorded on a bruker AVII $400 \mathrm{MHz}$ spectrometer. The chemical shifts were reported in (ppm) using the 7.26 signal of $\mathrm{CDCl}_{3}\left({ }^{1} \mathrm{H}-\mathrm{NMR}\right)$ as internal standards. ${ }^{13} \mathrm{C}$-NMR spectra $(100 \mathrm{MHz})$ were recorded on a bruker AVII $100 \mathrm{MHz}$ spectrometer. The chemical shifts were reported in (ppm) using the 77.0 signal of $\mathrm{CDCl}_{3}\left({ }^{13} \mathrm{C}-\mathrm{NMR}\right)$ as internal standards.

Procedure for the Preparation of Compound 2-10.

(E)-methyl 3-(4-nitrophenyl)acrylate (2): Compound 1 (25 g, $120 \mathrm{mmol}$ ) dissolved in $125 \mathrm{ml}$ methanol, stirred until the material dissolved. Then $\mathrm{H}_{2} \mathrm{SO}_{4}$ (conc.) (2 g) was added slowly. Then reflux the solution overnight until the material consumed well. After check the TLC, filtered the solution to get the compound 2 ( $25 \mathrm{~g}$, Yield $=93 \%$ ). ${ }^{1} \mathrm{H}-\mathrm{NMR}\left(400 \mathrm{MHz}, \mathrm{CDCl}_{3}\right) \delta: 3.84(\mathrm{~s}, 3 \mathrm{H}), 6.57(\mathrm{~d}, J=16.0 \mathrm{~Hz}, 1 \mathrm{H})$, 7.66-7.71 (m, 2H), $7.23(\mathrm{~d}, J=16.0 \mathrm{~Hz}, 1 \mathrm{H}), 8.24-8.27(\mathrm{~m}, 2 \mathrm{H})$.

(E)-methyl 3-(4-aminophenyl)acrylate (3): Compound 2 (20 g, $100 \mathrm{mmol}$ ) was dissolved in $160 \mathrm{ml}$ of THF and $80 \mathrm{ml}$ of methanol and stirred. $\mathrm{NH}_{4} \mathrm{Cl}(48 \mathrm{~g}, 900 \mathrm{mmol})$ dissolved in $80 \mathrm{ml}$ of water and the solution was added. Then add Fe $(21.5 \mathrm{~g}, 400 \mathrm{mmol})$ and stirred. The reaction mixture was refluxed about $5 \mathrm{~h}$. Afterwards check the TLC, filtered the solution. The solvent was poured into $\mathrm{NaHCO}_{3}$ (aq.), to make $\mathrm{pH}-8$, extracted with EtOAc, washed with water and brine/ dried over $\mathrm{Na}_{2} \mathrm{SO}_{4}$. Then concentrated the organic phase to develop compound 3 (5.25 g, Yield=30\%). ${ }^{1} \mathrm{H}-\mathrm{NMR}\left(400 \mathrm{MHz}, \mathrm{CDCl}_{3}\right) \delta: 3.74$ (s, $3 \mathrm{H}), 3.96$ (d, J=3.2 Hz, 2H), $6.24(\mathrm{~d}, J=16.0 \mathrm{~Hz}, 1 \mathrm{H}), 6.64-6.66$ (m, 2H), 7.26-7.36 (m, 2H), $7.61(\mathrm{~d}, J=16.0 \mathrm{~Hz}, 1 \mathrm{H})$.

(E)-methyl 3-(4-(tert-butoxycarbonylamino)phenyl)acrylate (4): Compound 3 (5 g, $28 \mathrm{mmol}$ ) and Di-tert-butyl dicarbonate(Boc anhydride) (12.3 g, $56 \mathrm{mmol}$ ) dissolved in $50 \mathrm{ml}$ dry THF and stirred. Then added $40 \mathrm{ml}$ of Triethylamine and heated reflux overnight. After checking the TLC, concentrated to get the crude product. The crude product was then chromatographed (10:1- petroleum ether/EtOAc) to afforded compound 4 (6.8 g, Yield=95\%). ${ }^{1} \mathrm{H}-\mathrm{NMR}\left(400 \mathrm{MHz}, \mathrm{CDCl}_{3}\right)$ $\delta: 1.52(\mathrm{~s}, 9 \mathrm{H}), 3.80(\mathrm{~s}, 3 \mathrm{H}), 6.35(\mathrm{~d}, J=16.0 \mathrm{~Hz}, 1 \mathrm{H}), 6.66(\mathrm{~s}, 1 \mathrm{H}), 7.38$ $7.47(\mathrm{~m}, 4 \mathrm{H}), 7.64(\mathrm{~d}, J=16.0 \mathrm{~Hz}, 1 \mathrm{H})$.

(E)-tert-butyl 4-(3-hydroxyprop-1-enyl)phenylcarbamate (5): Compound 4 (7 g, $25 \mathrm{mmol})$ dissolved in $70 \mathrm{ml} \mathrm{DCM}$ at $-65^{\circ} \mathrm{C}$ and stirred. Then DIBAl-H (8.97 g, $63 \mathrm{mmol})$ added drop wise. After finish the dropping, stirred the solution at RT for $3 \mathrm{~h}$. Afterwards check the TLC, the reaction was quenched with $\mathrm{KNaC}_{4} \mathrm{H}_{4} \mathrm{O}_{6} \cdot 4 \mathrm{H}_{2} \mathrm{O}$, extracted with EtOAc, washed with water and brine/dried over $\mathrm{Na}_{2} \mathrm{SO}_{4}$. Then<smiles>COC(=O)/C=C/c1ccc(N)cc1</smiles>

(01)

(02)

(03)<smiles>CCC(C)(C)OC(=O)Nc1ccc(/C=C/C(=O)OC)cc1</smiles>

(04)

(05)<smiles></smiles>

(06)

(07)<smiles></smiles>

(08)

(09)

(10)

Figure 1: (a) $\mathrm{CH}_{3} \mathrm{OH}, \mathrm{H}_{2} \mathrm{SO}_{4}$, reflux, overnight, 93\%; (b) $\mathrm{NH}_{4} \mathrm{Cl}$, THF, Fe, reflux, $5 \mathrm{~h}, 30 \%$; (c) (Boc) ${ }_{2} \mathrm{O}$, THF, TEA, reflux, overnight, 95\%; (d) DIBAl-H, DCM, -65으, $3 \mathrm{~h}, 68 \%$; (e) $\mathrm{CH}_{3} \mathrm{COOH}, \mathrm{NaNO}_{2}, 40^{\circ} \mathrm{C}, 3 \mathrm{~h}, 86 \%$; (f) DMP, DCM, rt, overnight, $94 \%$; (g) $\mathrm{NH}_{4} \mathrm{OH} . \mathrm{HCl}, \mathrm{EtOH}, \mathrm{Pyridine}^{\circ}, 95^{\circ} \mathrm{C}, 1 \mathrm{~h}, 80 \%$; (h) SOCl$, \mathrm{DMF}_{2} 0^{\circ} \mathrm{C}, 10 \mathrm{~min}$, rt, $1 \mathrm{~h}, 80 \%$; (i) TFA, DCM, $0^{\circ} \mathrm{C}, 5 \mathrm{~min}, \mathrm{rt}, 5 \mathrm{~h}, 82 \%$. 
concentrated the organic phase to get compound 5 ( $4.25 \mathrm{~g}$, Yield $=68 \%)$. ${ }^{1} \mathrm{H}-\mathrm{NMR}\left(400 \mathrm{MHz}, \mathrm{CDCl}_{3}\right) \delta: 1.52(\mathrm{~s}, 9 \mathrm{H}), 4.29-4.32(\mathrm{~m}, 2 \mathrm{H}), 6.24-$ $6.31(\mathrm{~m}, 1 \mathrm{H}), 6.51(\mathrm{~s}, 1 \mathrm{H}), 6.53-6.58(\mathrm{~m}, 1 \mathrm{H}), 7.32(\mathrm{~s}, 4 \mathrm{H})$.

4-(4-tert-butoxucarbonylamino)phenyl)-3-(hydroxymethyl)1,2,5-oxadiazole-2-oxide(6): Compound 5 (3 g, $12 \mathrm{mmol}$ ) was dissolved in $50 \mathrm{ml}$ of acetic acid and stirred. Then a solution of $\mathrm{NaNO}_{2}(2.08 \mathrm{~g}, 30 \mathrm{mmol})$ was added drop wise in $20 \mathrm{ml}$ of water,

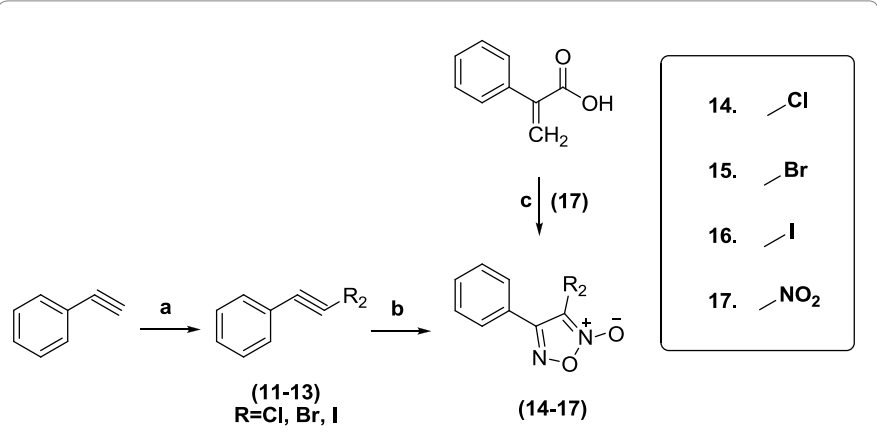

Figure 2: (b) $\mathrm{NaNO}_{2}, \mathrm{H}_{2} \mathrm{SO}_{4}, \mathrm{DME},-5 \mathrm{C}$, rt, overnight, 29-30\%; (c) $\mathrm{NaNO}_{2}$, $\mathrm{H}_{2} \mathrm{SO}_{4}, \mathrm{DCE}, 50^{\circ} \mathrm{C}, 1 \mathrm{~h}, 71 \%$. the reaction mixture was stirred at $40^{\circ} \mathrm{C}$ for $3 \mathrm{~h}$. After that check the TLC, the reaction residue was poured into $\mathrm{NaHCO}_{3}$ (aq.), to make $\mathrm{p}^{\mathrm{H}}-7$, extracted with EtOAc, washed with water and brine/dried over $\mathrm{Na}_{2} \mathrm{SO}_{4}$ and concentrated to get the crude product. The crude product was then chromatographed (10:1- petroleum ether/EtOAc) to afforded compound 6 (3.2 g, Yield $=86 \%) .{ }^{1} \mathrm{H}-\mathrm{NMR}\left(400 \mathrm{MHz}^{\mathrm{CDCl}}\right) \delta: 1.54$ (s, 9H), 4.75 (d, J=6.4 Hz, 2H), 7.53-7.56 (m, 2H), 7.74-7.77 (m, 2H); ${ }^{13} \mathrm{C}-\mathrm{NMR}\left(100 \mathrm{MHz}, \mathrm{CDCl}_{3}\right) \delta: 28.5,52.6,80.1,115.5,118.7,120,128.8$, $142.9,153.1,157.3$.

4-(4-(tert-butoxycarbonylamino)phenyl)-3-formyl-1,2,5oxadiazole-2-oxide (7): Compound $6(3.2 \mathrm{~g}, 10 \mathrm{mmol})$ dissolved in 50 $\mathrm{ml}$ of DCM and Dess Martin Periodinane (5.3 g, $12 \mathrm{mmol}$ ) was added. The solution was stirred overnight at RT. After checking the TLC, the solution was filtered, the filtered cake was washed with DCM twice. Combine the filtrate, washed with $\mathrm{NaHCO}_{3}$ (aq.), extracted with EtOAc, washed with water and brine/dried over $\mathrm{Na}_{2} \mathrm{SO}_{4}$ and concentrated to get compound 7 (3 g, Yield=94\%). ${ }^{1} \mathrm{H}-\mathrm{NMR}\left(400 \mathrm{MHz}^{2} \mathrm{CDCl}_{3}\right) \delta: 1.47$ (s, 9H), 4.05 (q, J=8.0 Hz, 1H), 7.43-7.48 (m, 2H), 7.80-7.83 (m, 2H).

(E) - 4 - ( 4 - ( t ert - butoxycarbonylamino) phenyl) - 3 ((hydroxyimino)methyl)-1,2,5-oxadiazole-2-oxide (8): Compound 7 (3 g, $9 \mathrm{mmol}$ ) was dissolved in $10 \mathrm{ml}$ of Ethanol and stirred. Then $\mathrm{NH}_{4} \mathrm{OH} . \mathrm{HCl}(857 \mathrm{mg}, 12 \mathrm{mmol})$ and Pyridine $(1.01 \mathrm{~g}, 12 \mathrm{mmol})$ was added. The solution was stirred at $95^{\circ} \mathrm{C}$ for $1 \mathrm{~h}$. TLC showed that the

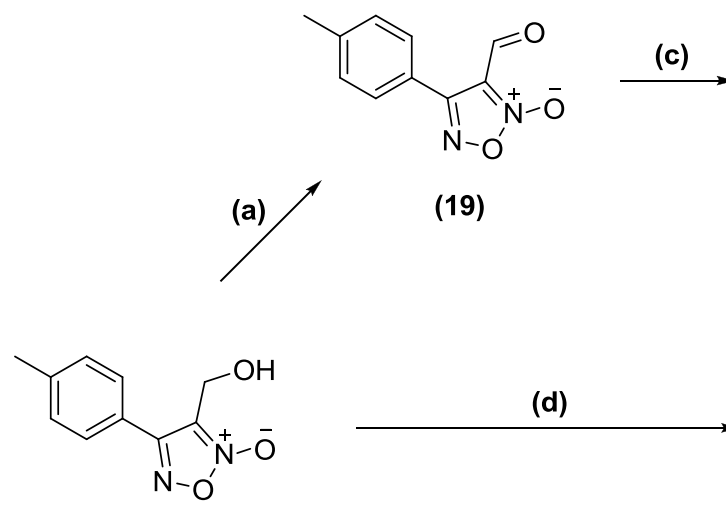

(18)<smiles>Cc1ccc(-c2no[n+]([O-])c2CBr)cc1</smiles>

(20)<smiles>[R]Cc1c(-c2ccc(C)cc2)no[n+]1[O-]</smiles>

(21-22)<smiles>[R]Cc1c(-c2ccc(C)cc2)no[n+]1[O-]</smiles>

(23-27)

(e)<smiles>[R]Cc1c(-c2ccc(C)cc2)no[n+]1[O-]</smiles>

(28)

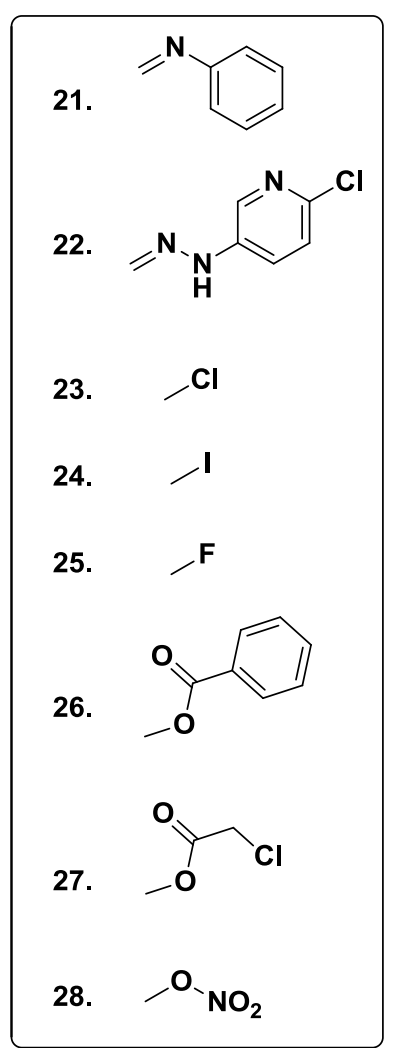

Figure 3: Synthesis of compounds 19-28. Reagents and condition: (a) DMP, DCM, rt, overnight, $90 \%$; (b) $\mathrm{PBr}_{3}, \mathrm{DCM}, 0^{\circ} \mathrm{C}, 2 \mathrm{~h}, 68 \%$; (c) $\mathrm{CH}_{3} \mathrm{OH}, \mathrm{rt}, 2 \mathrm{~h}, 40-59 \%$; (d) aromatic compounds, $\mathrm{DCM}, 0^{\circ} \mathrm{C}-\mathrm{rt}, 2 \mathrm{~h}-5 \mathrm{~h}, 73-80 \%$; (e) $\mathrm{AgNO}_{3}, \mathrm{CH}_{3} \mathrm{CN}$, Light protected, $70^{\circ} \mathrm{C}, 5 \mathrm{~h}, 64 \%$. 
Citation: C M A Gause M, Wen-Hua F, Li-Jun S, Chuan-Xin Y, Bainian F (2017) Synthesis and SAR Studies of New Oxadiazole-2-oxide Derivatives with Remarkable In Vitro Activity against Schistosoma japonicum. J Microb Biochem Technol 9: 535-543. doi: 10.4172/1948-5948.1000339

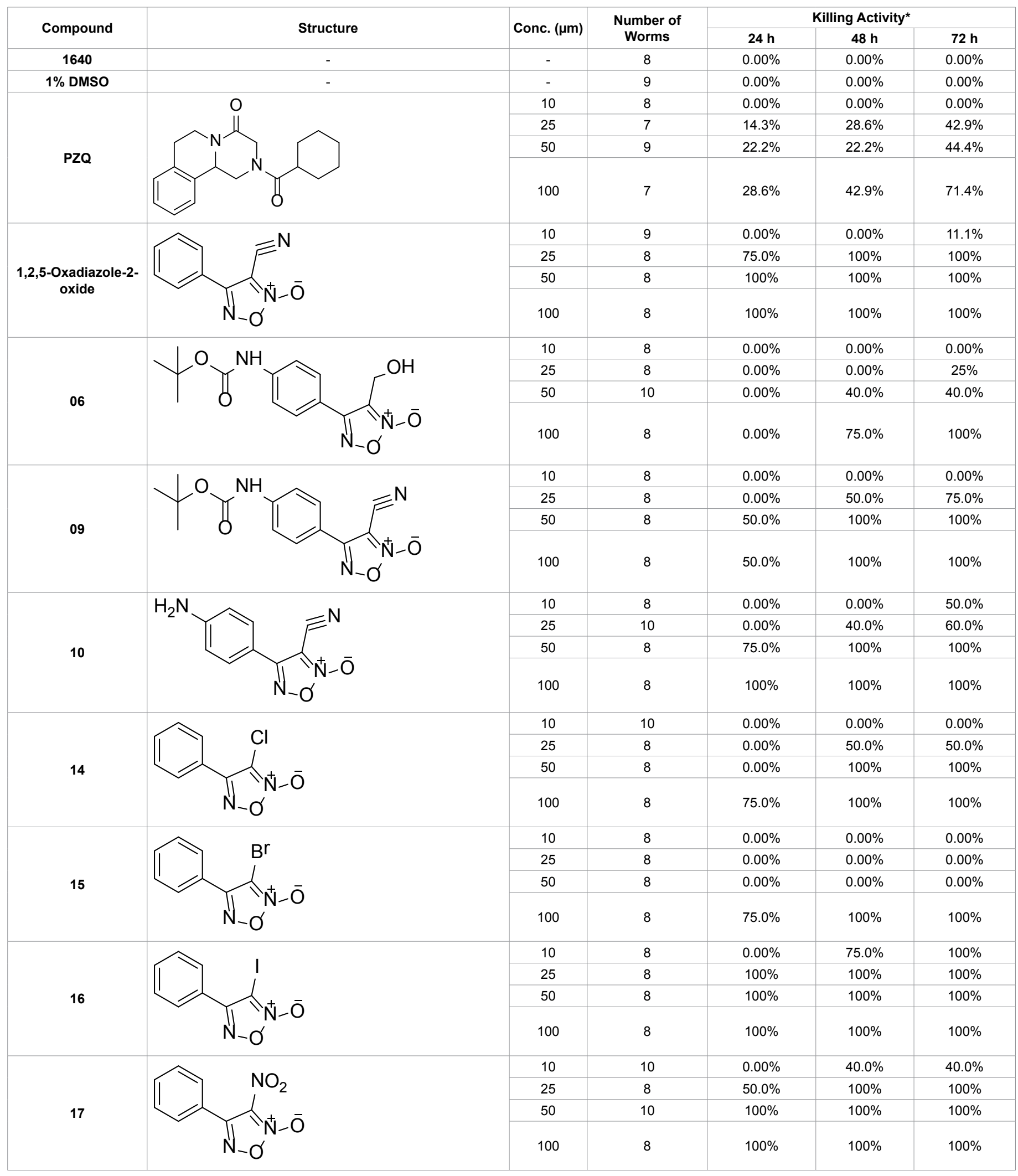


Citation: C M A Gause M, Wen-Hua F, Li-Jun S, Chuan-Xin Y, Bainian F (2017) Synthesis and SAR Studies of New Oxadiazole-2-oxide Derivatives with Remarkable In Vitro Activity against Schistosoma japonicum. J Microb Biochem Technol 9: 535-543. doi: 10.4172/1948-5948.1000339

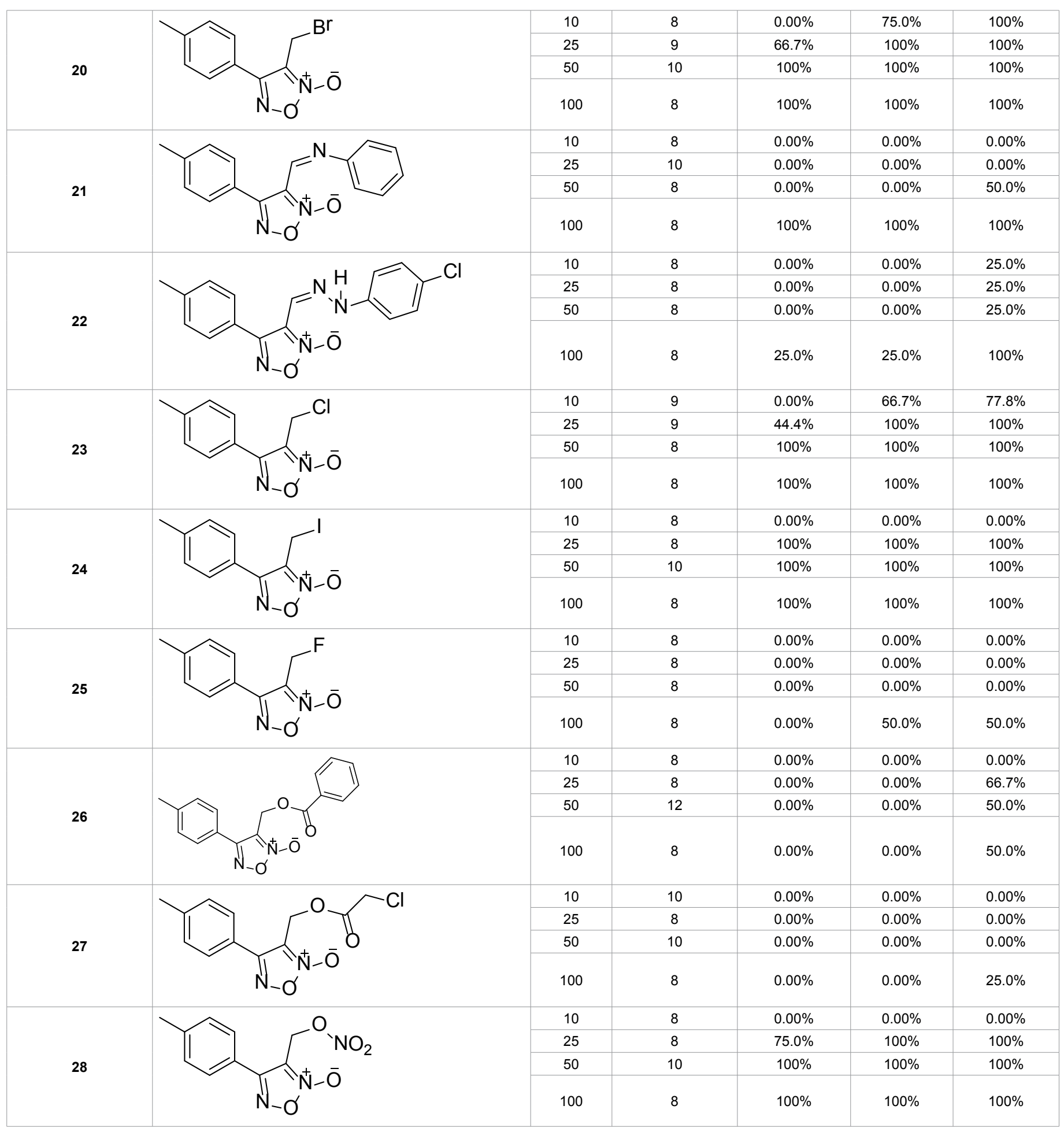

Table 1: Worm-killing activity on S. japonicum adult worms in vitro (Only the active compound).

*Data collected by visual examination of worm movement and shape; The number of worms dead/the total number of worms observed and worms dead judged by unclear internal structure of juvenile worms with uncompleted tegument and contents overflowing radically or unclear internal structure with complete tegument, but having no motor activity during $1 \mathrm{~min}$ of continuous observation. The data presented are the average of three independent experiments. (1640 without any drugs in the negative control; $1 \%$ DMSO to join themaximum drug concentration of DMSO concentration; PZQ for praziquantel at different concentrations on adults killing effect, as a positive control.)

material was consumed. Then $\mathrm{NH}_{4} \mathrm{OH} . \mathrm{H}_{2} \mathrm{O}$ was added to make the $\mathrm{pH}-7$, extracted with EtOAc, washed with water and brine/dried over $\mathrm{Na}_{2} \mathrm{SO}_{4}$ and concentrated to get the crude product. The crude product was then chromatographed (10:1- petroleum ether/EtOAc) to afforded compound 8 (2.5 g, Yield=80\%). ${ }^{1} \mathrm{H}-\mathrm{NMR}\left(400 \mathrm{MHz}, \mathrm{CDCl}_{3}\right) \delta: 1.53$ (s, $9 \mathrm{H}), 7.49-7.54(\mathrm{~m}, 2 \mathrm{H}), 7.66-7.84(\mathrm{~m}, 2 \mathrm{H}), 8.05(\mathrm{~s}, 1 \mathrm{H})$. 
4-(4-(tert-butoxycarbonylamino) phenyl)-3-cyano-1,2,5oxadiazole-2-oxide (9): Compound 8 ( $2 \mathrm{~g}, 6 \mathrm{mmol})$ was dissolved in $30 \mathrm{ml}$ of Dimethylformamide at $0^{\circ} \mathrm{C}$ and stirred. Then $\mathrm{SOCl}_{2}(1.8 \mathrm{ml}, 24$ $\mathrm{mmol}$ ) was added slowly at $0^{\circ} \mathrm{C}$. Stirred at $0^{\circ} \mathrm{C}$ for $10 \mathrm{~min}$. Then stirred at $\mathrm{RT}$ for $1 \mathrm{~h}$. After checking the TLC, slowly added $\mathrm{NH}_{3}$ solution then filter and concentrated to get the compound $9(1.5 \mathrm{~g}$, Yield $=80 \%)$. ${ }^{1} \mathrm{H}-\mathrm{NMR}\left(400 \mathrm{MHz}, \mathrm{CDCl}_{3}\right) \delta: 1.54(\mathrm{~s}, 9 \mathrm{H}), 7.58(\mathrm{~d}, J=8.0 \mathrm{~Hz}, 2 \mathrm{H}), 7.86$ $(\mathrm{d}, J=8.0 \mathrm{~Hz}, 2 \mathrm{H}) ;{ }^{13} \mathrm{C}-\mathrm{NMR}\left(100 \mathrm{MHz}, \mathrm{CDCl}_{3}\right) \delta: 28.5,80.4,108,117.5$, $118.9,128.2,144,153,155.1$

4-(4-aminophenyl)-3-cyano-1,2,5-oxadiazole-2-oxide (10): Compound 9 (1 g, $3 \mathrm{mmol}$ ) was dissolved in DCM and stirred at $0^{\circ} \mathrm{C}$. Then add TFA $(1.51 \mathrm{~g}, 13 \mathrm{mmol})$ was added at $0^{\circ} \mathrm{C}$ and stirred for $5 \mathrm{~min}$. The solution then stirred at RT for $5 \mathrm{~h}$. After checking the TLC, the reaction residue was poured into $\mathrm{NaHCO}_{3}$ (aq.), to make $\mathrm{pH}-7$, extracted with EtOAc, washed with water and brine/dried over $\mathrm{Na}_{2} \mathrm{SO}_{4}$ and concentrated to get the crude product. The crude products were then chromatographed (10:1- petroleum ether/EtOAc) to afford compound 10 (550 mg, Yield=82\%). ${ }^{1} \mathrm{H}-\mathrm{NMR}\left(400 \mathrm{MHz}, \mathrm{CDCl}_{3}\right) \delta$ : $4.16(\mathrm{~s}, 2 \mathrm{H}), 6.76-6.79(\mathrm{~m}, 2 \mathrm{H}), 7.71-7.75(\mathrm{~m}, 2 \mathrm{H}) ;{ }^{13} \mathrm{C}-\mathrm{NMR}(100 \mathrm{MHz}$, $\left.\mathrm{CDCl}_{3}\right) \delta: 98,108.4,110.1,114.2,128.6,153.4,155.5$.

\section{General procedure for the preparation of compound 11-13}

Phenylacetylene (6 g, $51 \mathrm{mmol}$ ) was dissolved in $100 \mathrm{ml}$ of THF under $\mathrm{N}_{2}$ and cooled to $-78^{\circ} \mathrm{C}$. $\mathrm{n}$-BuLi $(44 \mathrm{ml}, 1.5 \mathrm{M}, 66 \mathrm{mmol}$ ) was added drop wise. The reaction mixture was stirred at $-78^{\circ} \mathrm{C}$ for 15 min and for further $15 \mathrm{~min}$ at $0^{\circ} \mathrm{C}$. Then the suspension was cooled to $-78^{\circ} \mathrm{C}$. For compound 11 ; NCS (66mmol), compound 12; NBS (66 $\mathrm{mmol}$ ) and compound 13; a solution of $\mathrm{I}_{2}$ in THF were added slowly. The reaction mixture was stirred for $1 \mathrm{~h}$ at $-78^{\circ} \mathrm{C}$ and for another $18 \mathrm{~h}$ at RT. After checking the TLC, add $\mathrm{NH}_{4} \mathrm{OH} \cdot \mathrm{H}_{2} \mathrm{O}$ was added to make the $\mathrm{pH}-7$, extracted with EtOAc, washed with water and brine/dried over $\mathrm{Na}_{2} \mathrm{SO}_{4}$ and concentrated to get the compound.

(Chloroethynyl)benzene (11): Yield $=70 \%$; ${ }^{1} \mathrm{H}-\mathrm{NMR}(400 \mathrm{MHz}$, $\left.\mathrm{CDCl}_{3}\right)$ 8: 7.28-7.36 (m, 3H), 7.43-7.51 (m, 2H).

(Bromoethynyl)benzene (12): Yield $=77 \% ;{ }^{1} \mathrm{H}-\mathrm{NMR}(400 \mathrm{MHz}$, $\left.\mathrm{CDCl}_{3}\right)$ \&: 7.24-7.36 (m, 3H), 7.43-7.50 (m, 2H).

(Iodoethynyl)benzene (13): Yield $=69 \%$; ${ }^{1} \mathrm{H}-\mathrm{NMR}(400 \mathrm{MHz}$, $\left.\mathrm{CDCl}_{3}\right)$ 8: 7.31-7.37 (m, 3H), 7.50-7.54 (m, 2H).

\section{General procedure for the preparation of compound 14-16}

Compound 11 13 (1 g, $7 \mathrm{mmol})$ dissolved in $20 \mathrm{ml}$ of DME at $-5^{\circ} \mathrm{C}$ and added $\mathrm{H}_{2} \mathrm{SO}_{4}(14 \mathrm{mmol})$ and $\mathrm{NaNO}_{2}(14 \mathrm{mmol})$. The solution was stirred at RT for overnight. After checking the TLC, the reaction residue was poured into $\mathrm{NaHCO}_{3}$ (aq.), extracted with EtOAc, washed with water and brine/dried over $\mathrm{Na}_{2} \mathrm{SO}_{4}$ and concentrated to get the crude product. The crude products were then chromatographed (30:1 10:1petroleum ether/EtOAc) to afford compound 14-16.

3-chloro-4-phenyl-1,2,5-oxadiazole 2-oxide (14): Yield $=30 \%$; ${ }^{1} \mathrm{H}-\mathrm{NMR}\left(400 \mathrm{MHz}, \mathrm{CDCl}_{3}\right)$ 8: 7.47-7.74 (m, 3H), 7.82-7.88 (m, $\left.1 \mathrm{H}\right)$, 8.16-8.22 (m, 1H).

3-bromo-4-phenyl-1,2,5-oxadiazole 2-oxide (15): Yield=29\%; ${ }^{1} \mathrm{H}-\mathrm{NMR}\left(400 \mathrm{MHz}, \mathrm{CDCl}_{3}\right)$ 8: 7.46-7.55 (m, 3H), 7.82-7.86 (m, $\left.1 \mathrm{H}\right)$, 8.16-8.18 (m, 1H).

3-iodo-4-phenyl-1,2,5-oxadiazole 2-oxide (16): Yield=29\%; ${ }^{1} \mathrm{H}-\mathrm{NMR}\left(400 \mathrm{MHz}, \mathrm{CDCl}_{3}\right) \delta:$ 7.50-7.63 (m, 3H), 7.67-7.74 (m, $\left.1 \mathrm{H}\right)$, 8.85-8.87 (m, 1H).

\section{Procedure for the Preparation of Compound 17 (3-nitro-4- phenyl-1,2,5-oxadiazole-2-oxide)}

2-Phenylacrylic acid (1 g, $6 \mathrm{mmol})$ was dissolved in $10 \mathrm{ml}$ of DCE and $\mathrm{H}_{2} \mathrm{SO}_{4}$ (conc.) $\left(9 \mathrm{mmol}\right.$ ) was added. Then $\mathrm{NaNO}_{2}(1.4 \mathrm{~g}, 21 \mathrm{mmol})$ was added slowly into the solution. The solution was stirred for $1 \mathrm{~h}$ at $50^{\circ} \mathrm{C}$. After checking the TLC, the reaction residue was poured into $\mathrm{Na}_{2} \mathrm{CO}_{3}$ (aq.), extracted with EtOAc, washed with water and brine/dried over $\mathrm{Na}_{2} \mathrm{SO}_{4}$ and concentrated to get the crude product. The crude products were then chromatographed (15:1- petroleum ether/EtOAc) to afford compound $17\left(1 \mathrm{~g}\right.$, Yield=71\%). ${ }^{1} \mathrm{H}-\mathrm{NMR}\left(400 \mathrm{MHz}, \mathrm{CDCl}_{3}\right)$ $\delta:$ 7.55-7.69 (m, 5H).

\section{Procedure for the preparation of compound 18-28}

3-formyl-4-p-tolyl-1,2,5-oxadiazole 2-oxide (19): Compound $18(500 \mathrm{mg}, 2.5 \mathrm{mmol}$ ) dissolved in $20 \mathrm{ml}$ of DCM and Dess Martin Periodinane $(1.23 \mathrm{gm}, 3 \mathrm{mmol})$ was added. The solution was stirred overnight at RT. After checking the TLC, the solution was filtered, the filtered cake was washed with DCM twice. Combine the filtrate, washed with $\mathrm{NaHCO}_{3}$ (aq.), extracted with EtOAc, washed with water and brine/dried over $\mathrm{Na}_{2} \mathrm{SO}_{4}$ and concentrated to get compound 19 (450 mg, Yield=90\%). ${ }^{1} \mathrm{H}-\mathrm{NMR}\left(400 \mathrm{MHz}, \mathrm{CDCl}_{3}\right) \delta: 2.38(\mathrm{~s}, 3 \mathrm{H}), 7.28(\mathrm{~d}$, $J=8.0 \mathrm{~Hz}, 2 \mathrm{H}), 7.73(\mathrm{~d}, J=8.0 \mathrm{~Hz}, 2 \mathrm{H}), 9.91(\mathrm{~s}, 1 \mathrm{H})$.

3-(bromomethyl)-4-p-tolyl-1,2,5-oxadiazole 2-oxide (20): Compound 18 ( $1 \mathrm{~g}, 4 \mathrm{mmol})$ dissolved in $10 \mathrm{ml}$ of DCM and cooled to $0^{\circ} \mathrm{C}$. Then $\mathrm{PBr}_{3}(0.5 \mathrm{ml}, 5 \mathrm{mmol})$ was added drop wise. The solution was stirred at this temperature for $2 \mathrm{~h}$. After checking the TLC, the reaction residue was poured into $\mathrm{NaHCO}_{3}$ (aq.) to make pH-7, extracted with EtOAc, washed with water and brine/dried over $\mathrm{Na}_{2} \mathrm{SO}_{4}$ and concentrated to get compound $20(884 \mathrm{mg}$, Yield $=68 \%) .{ }^{1} \mathrm{H}-\mathrm{NMR}$ $\left(400 \mathrm{MHz}, \mathrm{CDCl}_{3}\right) \delta: 2.46(\mathrm{~s}, 3 \mathrm{H}), 4.40(\mathrm{~s}, 2 \mathrm{H}), 7.38(\mathrm{~d}, J=8.0 \mathrm{~Hz}, 2 \mathrm{H})$, $7.83(\mathrm{~d}, J=8.0 \mathrm{~Hz}, 2 \mathrm{H}) ;{ }^{13} \mathrm{C}-\mathrm{NMR}\left(100 \mathrm{MHz}, \mathrm{CDCl}_{3}\right) \delta: 17.5,21.5,113.3$, $122.9,127.4,130.3,142.1,155.7$.

(E)-3-((phenylimino)methyl)-4-p-tolyl-1,2,5-oxadiazole 2-oxide (21): Compound 19 (100 mg, $0.5 \mathrm{mmol})$ and Phenylamine $(45 \mathrm{mg}, 0.5$ mmol) dissolved in $2 \mathrm{ml}$ of methanol and stirred at RT for $2 \mathrm{~h}$. After checking the TLC, concentrated the solution and chromatographed (30:1- petroleum ether/EtOAc) to afford compound 21 (80 gm, Yield=59\%). ${ }^{1} \mathrm{H}-\mathrm{NMR}\left(400 \mathrm{MHz}, \mathrm{CDCl}_{3}\right) \delta: 2.44(\mathrm{~s}, 3 \mathrm{H}), 7.20-7.22(\mathrm{~m}$, $2 \mathrm{H}), 7.30-7.33(\mathrm{~m}, 3 \mathrm{H}), 7.38-7.41(\mathrm{~m}, 2 \mathrm{H}), 7.89-7.91(\mathrm{~m}, 2 \mathrm{H}), 8.43(\mathrm{~s}$, $1 \mathrm{H}) ;{ }^{13} \mathrm{C}$-NMR $\left(100 \mathrm{MHz}, \mathrm{CDCl}_{3}\right) \delta: 20.5,113.2,120.1,121.8,122.1$, 127, 128.2, 128.3, 140.7, 149, 155.

(E)-3-((2-(6-chloropyridin-3-yl)hydrazono)methyl)-4-p-tolyl1,2,5-oxadiazole 2-oxide (22): Compound 19 (100 mg, $0.5 \mathrm{mmol})$ and 2-chloro-5-hydrazinylpyridine (70 $\mathrm{mg}, 0.5 \mathrm{mmol}$ ) dissolved in $3 \mathrm{ml}$ of methanol and stirred at RT for $2 \mathrm{~h}$. After checking the TLC, filtered the solution. Filtered cake(solid) is compound 22 (64 mg, Yield $=40 \%)$. ${ }^{1} \mathrm{H}-\mathrm{NMR}\left(400 \mathrm{MHz}, \mathrm{CDCl}_{3}\right) \delta: 2.49(\mathrm{~s}, 3 \mathrm{H}), 7.13-7.19(\mathrm{~m}, 2 \mathrm{H}), 7.35(\mathrm{~d}$, $J=7.6 \mathrm{~Hz}, 2 \mathrm{H}), 7.71(\mathrm{~d}, J=8.0 \mathrm{~Hz}, 2 \mathrm{H}), 8.01(\mathrm{~d}, J=2.4 \mathrm{~Hz}, 1 \mathrm{H}), 8.13(\mathrm{~s}$, $1 \mathrm{H})) ;{ }^{13} \mathrm{C}-\mathrm{NMR}\left(100 \mathrm{MHz}, \mathrm{CDCl}_{3}\right) \delta: 21.6,113.4,123.3,124,124.5,129$, $129.3,134.7,138.7,141.8,143.5,155.6$.

3-(chloromethyl)-4-p-tolyl-1,2,5-thiadiazole 2-oxide (23): Compound $18(50 \mathrm{mg}, 0.24 \mathrm{mmol})$ dissolved in $5 \mathrm{ml}$ of DCM at $0^{\circ} \mathrm{C}$. Then $\mathrm{SOCl}_{2}(85 \mathrm{mg}, 0.6 \mathrm{mmol})$ was added slowly at the same temperature. Then stirred at RT for $5 \mathrm{~h}$. After checking the TLC, the reaction residue was poured into $\mathrm{NaHCO}_{3}$ (aq.) to make $\mathrm{pH}-7$, extracted with EtOAc, washed with water and brine/dried over $\mathrm{Na}_{2} \mathrm{SO}_{4}$ and concentrated to get compound 23 (40 mg, Yield=74\%). ${ }^{1} \mathrm{H}-\mathrm{NMR}$ 
$\left(400 \mathrm{MHz}, \mathrm{CDCl}_{3}\right) \delta: 2.46(\mathrm{~s}, 3 \mathrm{H}), 4.59(\mathrm{~s}, 2 \mathrm{H}), 7.38(\mathrm{~d}, J=8.0 \mathrm{~Hz}, 2 \mathrm{H})$, $7.67(\mathrm{~d}, J=8.0 \mathrm{~Hz}, 2 \mathrm{H}) ;{ }^{13} \mathrm{C}-\mathrm{NMR}\left(100 \mathrm{MHz}, \mathrm{CDCl}_{3}\right) \delta: 21.5,32.8,113$, $123,127.8,130.3,142.1,156$

3-(iodomethyl)-4-p-tolyl-1,2,5-thiadiazole 2-oxide (24): Compound 18 (50 mg, $0.24 \mathrm{mmol})$ dissolved in $5 \mathrm{ml}$ of DCM and added $\mathrm{PPh}_{3}(94 \mathrm{mg}, 0.35 \mathrm{mmol})$ and stirred for $5 \mathrm{~min}$. Then imidazole $(21 \mathrm{mg}$, $0.3 \mathrm{mmol}$ ) was added and stirred another $5 \mathrm{~min}$ and cooled it down to $0^{\circ} \mathrm{C}$. Then add $\mathrm{I}_{2}(182 \mathrm{mg}, 0.7 \mathrm{mmol})$ was added slowly and stirred at RT for $2 \mathrm{~h}$. After checking the TLC, the reaction residues was poured into water, extracted with EtOAc, washed with water and brine/dried over $\mathrm{Na}_{2} \mathrm{SO}_{4}$ and concentrated to get the crude product. The crude products were then chromatographed (5:1- petroleum ether/EtOAc) to afford compound 24 (60 mg, Yield=79\%). ${ }^{1} \mathrm{H}-\mathrm{NMR}\left(400 \mathrm{MHz}, \mathrm{CDCl}_{3}\right) \delta: 2.46$ (s, $3 \mathrm{H}), 4.25$ (s, 2H), $7.39(\mathrm{~d}, J=8.0 \mathrm{~Hz}, 2 \mathrm{H}), 7.65(\mathrm{~d}, J=8.0 \mathrm{~Hz}, 2 \mathrm{H})$; ${ }^{13} \mathrm{C}-\mathrm{NMR}\left(100 \mathrm{MHz}, \mathrm{CDCl}_{3}\right) \delta: 13.6,21.6,114.7,123.2,127.4,130.3$, $142,155.2$.

3-(fluoromethyl)-4-p-tolyl-1,2,5-thiadiazole 2-oxide (25): Compound 18 (100 mg, $0.5 \mathrm{mmol}$ ) was dissolved in $5 \mathrm{ml}$ of DCM at $0^{\circ} \mathrm{C}$ and 1 drop of methanol was added and stirred. Then DAST (619 $\mathrm{mg}, 4 \mathrm{mmol}$ ) was added slowly at this temperature. The solution was stirred at $0^{\circ} \mathrm{C}$ for $1 \mathrm{~h}$. After checking the TLC, the reaction residues was poured into water, extracted with EtOAc, washed with water and brine/dried over $\mathrm{Na}_{2} \mathrm{SO}_{4}$ and concentrated to get the crude product. The crude products were then chromatographed (10:1- petroleum ether/EtOAc) to afford compound $25\left(80 \mathrm{mg}\right.$, Yield=79\%). ${ }^{1} \mathrm{H}-\mathrm{NMR}$ $\left(400 \mathrm{MHz}, \mathrm{CDCl}_{3}\right) \delta: 2.45$ (s, 3H), $5.40(\mathrm{~d}, J=48.0 \mathrm{~Hz}, 2 \mathrm{H}), 7.36-7.39$ $(\mathrm{m}, 2 \mathrm{H}), 7.65-7.69(\mathrm{~m}, 2 \mathrm{H}) ;{ }^{13} \mathrm{C}-\mathrm{NMR}\left(100 \mathrm{MHz}^{\mathrm{C}} \mathrm{CDCl}_{3}\right) \delta: 21.5,72.7$, $111.2,123,127.5,130.2,142.2,156.9$.

3-(benzoyloxymethyl)-4-p-tolyl-1,2,5-oxadiazole 2-oxide (26): Compound 18 (50 mg, $0.24 \mathrm{mmol}$ ) and Benzoyl Chloride (40 mg, 0.3 $\mathrm{mmol}$ ) was dissolved in $3 \mathrm{ml}$ of DCM and stirred. Then add TEA (36 $\mathrm{mg}, 0.35 \mathrm{mmol}$ ) was added and stirred at RT for $5 \mathrm{~h}$. After checking the TLC, the reaction residues was poured into water, extracted with EtOAc, washed with water and brine/dried over $\mathrm{Na}_{2} \mathrm{SO}_{4}$ and concentrated to get the crude product. The crude products were then chromatographed (10:1- petroleum ether/EtOAc) to afford compound 26 (60 mg, Yield=80\%). ${ }^{1} \mathrm{H}-\mathrm{NMR}\left(400 \mathrm{MHz}, \mathrm{CDCl}_{3}\right) \delta: 2.42(\mathrm{~s}, 3 \mathrm{H})$, $5.38(\mathrm{~s}, 2 \mathrm{H}), 7.32-7.34(\mathrm{~m}, 2 \mathrm{H})$, 7.43-7.47 (m, 2H), 7.54-7.66 (m, 3H), 7.99-8.00 (m, 2H); ${ }^{13} \mathrm{C}-\mathrm{NMR}\left(100 \mathrm{MHz}, \mathrm{CDCl}_{3}\right) \delta: 21.5,54.8,111.3$, 123.2, 127.5, 128.6, 128.7, 129.9, 130.1, 133.8, 142, 156.8, 165.7 .

3-((2-chloroacetoxy)methyl)-4-p-tolyl-1,2,5-oxadiazole 2-oxide (27): Compound 18 (50 mg, $0.24 \mathrm{mmol}$ ) and Chloroacetyl chloride (40 $\mathrm{mg}, 0.3 \mathrm{mmol}$ ) was dissolved in $3 \mathrm{ml}$ of DCM and stirred. Then add TEA (36 $\mathrm{mg}, 0.35 \mathrm{mmol}$ ) and stirred at RT for $5 \mathrm{~h}$. After checking the TLC, the reaction residues was poured into water, extracted with EtOAc, washed with water and brine/dried over $\mathrm{Na}_{2} \mathrm{SO}_{4}$ and concentrated to get the crude product. The crude products were then chromatographed (10:1petroleum ether/EtOAc) to afford compound 27 (50 mg, Yield=73\%). ${ }^{1} \mathrm{H}-\mathrm{NMR}\left(400 \mathrm{MHz}, \mathrm{CDCl}_{3}\right) \delta: 2.45$ (s, 3H), 4.11 (s, 2H), 5.25 (s, 2H), 7.35-7.36 (m, 2H), 7.57-7.59 (m, 2H); ${ }^{13} \mathrm{C}-\mathrm{NMR}\left(100 \mathrm{MHz}, \mathrm{CDCl}_{3}\right) \delta$ : $21.5,40.2,55.6,110.7,123,127.5,130.2,142.1,156.7,166.6$.

3-(nitrooxymethyl)-4-p-tolyl-1,2,5-thiadiazole 2-oxide (28): Compound 20 (50 mg, $0.19 \mathrm{mmol}$ ) was dissolved in $2 \mathrm{ml}$ of Acetonitrile and $\mathrm{AgNO}_{3}(75 \mathrm{mg}, 0.7 \mathrm{mmol}$ ) was added into a flask protected from light. The suspension was stirred for $5 \mathrm{~h}$ at $70^{\circ} \mathrm{C}$. After cooling to room temperature, the solution was filtered, the solvent was concentrated, then extracted with EtOAc, the water phase washed again with two times, then combine the organic phase and brine/dried over $\mathrm{Na}_{2} \mathrm{SO}_{4}$ and concentrated to get compound 28 (30 mg, Yield $=64 \%)$. ${ }^{1} \mathrm{H}-\mathrm{NMR}$ $\left(400 \mathrm{MHz}, \mathrm{CDCl}_{3}\right) \delta:: 2.46(\mathrm{~s}, 3 \mathrm{H}), 5.49(\mathrm{~s}, 2 \mathrm{H}), 7.37(\mathrm{~d}, J=8.0 \mathrm{~Hz}, 2 \mathrm{H})$, $7.57(\mathrm{~d}, J=8.0 \mathrm{~Hz}, 2 \mathrm{H}) ;{ }^{13} \mathrm{C}-\mathrm{NMR}\left(100 \mathrm{MHz}, \mathrm{CDCl}_{3}\right) \delta: 21.5,61.8,108.9$, 122.6, 127.5, 130.3, 142.4, 156.7 .

Parasites killing activity of compounds 2-28 on Schistosoma japonicum adult worms in vitro: Compounds 2-28 solutions and praziquantel were prepared by dissolving $1 \mathrm{mg}$ of the drugs in $0.4 \mathrm{ml}$ dimethyl sulfoxide (DMSO) and by adding $0.6 \mathrm{ml}$ RPMI 1640 medium. S. japonicum worms obtained from mice (C57BL/6, female, 22-24 g, each of them was infected with 50 cercariae) were washed in RPMI 1640 medium, kept at pH 7.5 with HEPES $20 \mathrm{mM}$ and supplemented with penicillin $(100 \mathrm{UI} / \mathrm{ml})$, streptomycin $(100 \mathrm{mg} / \mathrm{ml})$ and $10 \%$ fetal bovine serum (FBS, Gibco). Centrifugation was performed for $1 \mathrm{~min}$ at 1500 $\mathrm{rpm}$. After centrifugation, the supernatant solution was removed. The cercariae at the bottom were washed twice and resuspended with RPMI 1640. Approximately 8-20 cercariae ( $1 \mathrm{ml}$ of the resuspension medium) were added to one well in a 24 well culture plate. They were incubated overnight at $37^{\circ} \mathrm{C}$ with $5 \% \mathrm{CO}_{2}$ and then different concentrations of compounds 2-28 (10, 25, 50, $100 \mu \mathrm{M})$ diluted with RPMI 1640 medium were added. Control worms were treated with equal volumes of RPMI 1640 or DMSO, and worms treated with $10,25,50,100 \mu \mathrm{M}$ praziquantel were also observed. The worm mobility, tegumental alterations and parasite survival were monitored under an inverted microscope (Leica, Wetzlar, Germany) at 24, 48 and $72 \mathrm{H}$. Parasite death was defined as having no motor activity during $2 \mathrm{~min}$ of continuous observation as well as morphological and tegumental alterations. The tests were repeated two times when compounds showed worm killing activity below the concentration of $100 \mu \mathrm{M}$.

\section{Results}

\section{Chemistry}

As shown in Figure 1, we designed compound $\mathbf{1 0}$ with adding amine functional group to position 1 substitution and examined the worm killing activities against Schistosoma japonicum. During the chain reaction, we found compound $\mathbf{6}$ and compound $\mathbf{9}$ also have worm killing activities against Schistosoma japonicum.

From the Figure 1, compound $\mathbf{1}$ was esterified with methyl to develop compound 2, where it was reduced by Fe to get the compound 3. The amino was protected with (Boc) ${ }_{2} \mathrm{O}$ at $80-90^{\circ} \mathrm{C}$ to afford the compound 4, followed by closing the ring with $\mathrm{NaNO}_{2}$ The hydroxyl was oxidized with Dess-Martin Periodinane at room temperature with yield $94 \%$ to get the aldehyde. To extend compound 8 reacted with $\mathrm{NH}_{2} \mathrm{OH} . \mathrm{HCl}$ to get the oxime, then hydrolyzed to get cyano compound 9. Finally it was deprotection with TFA to get the compound $\mathbf{1 0}$ with a yield of $82 \%$.

As the earlier reports, we found that 3-(bromomethyl)-4-phenyl1,2,5-oxadiazole 2-oxide exhibited activity against Schistosoma japonicum. So, we designed some new analogues changing its position 13 substitutions with different atoms. The halogenated group includes chloride $(-\mathrm{Cl})$, iodide $(-\mathrm{I})$, bromide $(-\mathrm{Br})$, nitrogen dioxide $\left(-\mathrm{NO}_{2}\right)$. In, phenylacetylene react with a thiolate salt presence of an amine mediator with excellent yields ranging from $65-80 \%$ (Compound 11-13). Then it was thermal isomerization with $\mathrm{NaNO}_{2}$ and $\mathrm{H}_{2} \mathrm{SO}_{4}$ (conc.) to afford the compound 14-16. Compound 17 obtained by domino reaction of 
acrylic acids with action of sodium nitrite $\mathrm{NaNO}_{2}$.

After getting the activity result of Figures 1 and 2, we resynthesized and design more analogues by changing the same position 13 with halide and other atoms. The title 1,2,5-oxadiazole-2-oxide derivatives shown in Figure 3, wherein, $\mathrm{R}$ includes methylene chloride, methylene iodide, methylene fluoride, n-methyleneaniline, 2-chloro5-(2-methylenehydrazinyl) pyridine, methyl benzoate, methyl 2-chloroacetate, methyl nitrate which all show worm killing activity against Schistosoma japonicum.

\section{Biological activities}

We checked the biological activities from compound 2-28, among them most of the compound showed good worm killing activities. Table 1 contains the compound which is only showing activities.

\section{Discussion}

On the basis of Figures 1-3, we checked their worm killing activity. Among the 28 compounds, 16 compounds showed worm killing activity. Table 1 shows the list of that compound. Compound 6 containing a hydroxyl group killed $100.0 \pm 0.0 \%$ of worms at $100 \mu \mathrm{M}$ in $72 \mathrm{~h}$. Continuation the chain reaction compound $\mathbf{7}$ and $\mathbf{8}$ have not shown any activity. Compound 9 with a cyano group and position 1 with Boc anhydride has also shown good worm killing activity, concentration of $50 \mu \mathrm{M}$ in $48 \mathrm{~h}$. Compound 10 by changing the 1 position with an amine functional group also exhibits same activity. So, we believe cyano group and hydroxyl group is important factor against the killing activity.

Comparing with earlier compounds, compounds 14-16 changed the cyano group with halogen atom showed good worm killing activity ever. Compound 14 containing a chloro atom killed $100.0 \pm 0.0 \%$ of worms at $50 \mu \mathrm{M}$ in $48 \mathrm{~h}$, while compound 15 containing bromo atom killed $100.0 \pm 0.0 \%$ of worms at $100 \mu \mathrm{M}$ in $48 \mathrm{~h}$. Compound 16 showed excellent activity which contains an iodine atom that killed $100.0 \pm$ $0.0 \%$ of worms at $10 \mu \mathrm{M}$ in $72 \mathrm{~h}$. Compound 17 containing a nitro group in position 3, also have better activity than other compounds. In here, there are no cyano groups, but still they have shown good activity against the Schistosoma japonicum. Halogen atom could be a new kind to treat schistosomiasis, where it killed all worms at very low concentration with very short period of time.

By increasing the ring size of oxadiazole-2-oxide analogues, Compound $\mathbf{2 1}$ and compound $\mathbf{2 2}$ contains a phenylamino and chloropyridin atom also showed worm killing activity. Following the compound 20, 23, 24 also showed best result. These compounds containing a $\mathrm{CH}_{2}$ with Bromo, chloro, Iodine atom killed $100.0 \pm 0.0 \%$ of worms. Compound 24 killed $100.0 \pm 0.0 \%$ of worms at $25 \mu \mathrm{M}$ in $24 \mathrm{~h}$. If we see the compound $\mathbf{1 6}$ and $\mathbf{2 4}$, both containing an iodine atom but compound 24 contains an additional $\mathrm{CH}_{2}$ bond. We believe, iodine could have an important role in killing worms because of its low concentration of killing activity. Also, if we compare compound $\mathbf{1 5}$ and compound 20, bromide makes an excellent activity in which we believe its electron withdrawn group. Compound $\mathbf{2 6}$ and $\mathbf{2 7}$ have also showed better activity than PZQ. Compound 28 containing nitro-oxymethyl group killed $100.0 \pm 0.0 \%$ of worms at $25 \mu \mathrm{M}$ in $48 \mathrm{~h}$. If we check the structure of $\mathbf{1 7}$ and $\mathbf{2 8}$ they are similar and their activity is almost same. So, nitro group could be a new way of treatment. Evaluation of their cytotoxity is in progress. This structure activity relationship (SAR) could have important implications for further drug development of the oxadiazole-2-oxides against schistosomiasis. The oxadiazole-2-oxide core is a class of NO donating compounds [22]. These compounds show us that schistosomiasis may have other targets, while different compounds work on different target group. The killing activities were done against the adult worms. This study helps us to synthesize some novel oxadiazole-2-oxide analogues to kill the worm also their structure activity relationship with it. There is a great chance to combined therapy with these compounds to control the schistosomiasis.

\section{Conclusion}

The designs and synthesizes of novel 1,2,5-oxadiazole-2-oxide analogues are relatively simple in structure and easy to prepare and could be used for preparation of medicaments for treatment of schistosomiasis, and have the same effect as commercial drugs and can overcome the poor efficacy of the existing anti-schistosomiasis drug-induced drug resistance or ineffective treatment. The only chemotherapy PZQ has the potential of risk to prevent widespread of schistosomiasis all over the world. There is an urgent need of new agent, which can work against both juvenile and adult worms. We should select one suitable and appropriate candidate to developed and employed. In this work, we studied about 1,2,5-oxadiazole-2-oxide and its related previous published journal. We believe its analogue can be a potential candidate for treatment of schistosomiasis. Some of these were shown very good result during the in-vitro process. The progress regarding in vivo activity and toxicity will be reported later on.

\section{Acknowledgement}

This work was supported by grants from the National Natural Science Foundation of China (Nos. 30972581, 8120316), the Natural Science Foundation of Jiangsu Province, China (Nos. BK2012544, BK20151120), the Laboratory Research of Parasitic Disease Prevention and Control Platform (No. wk014-002) and Jiangsu Science and Technology Department (No. BM2015024).

\section{References}

1. Allen GPR, Adrian CS, Richard Olds G, Yuesheng L, Gail MW, et al. (2002) Schistosomiasis. N Engl J Med 346: 1212-1220.

2. Marianette TI, Remigio MO, Thao NPC, David UO, Allen GPR (2014) Prevention and control of schistosomiasis: A current perspective. Res Rep Trop Med 5: 65-75.

3. Utzinger J, Becker SL, van Lieshout L, van Dam GJ, Knopp S (2015) New diagnostic tools in schistosomiasis. Clin Microbiol Infect 21: 529-542.

4. Olveda DU, Li Y, Olveda RM, Lam AK, Chau TN, et al. (2013) Bilharzia: Pathology, diagnosis, management and control. Trop Med Surg 1.

5. Ahmed AS, Anton S, Craig JT, James I, Christopher PA, et al. (2008) Identification of oxadiazoles as new drug leads for the control of schistosomiasis. Nature Medicine 14: 407-412.

6. Chen MG (1991) Relative distribution of Schistosoma japonicum eggs in the intestine of man: A subject of inconsistencies. Acta Trop 48: 163-171.

7. Chai JY (2013) Praziquantel treatment in trematode and cestode infections: An update. Infect Chemother 45: 32-43.

8. Weller PFLK (2005) Diagnosis and treatment of schistosomiasis.

9. Herwaldt BL TL, Van Pelt W, Tsang VC, Bruce Jl (1995) Persistence of Schistosoma haematobium infection despite multiple courses of therapy with praziquantel. Clin Infect Dis 20: 309-315.

10. Fallon PG, Doenhoff MJ (1994) Drug-resistant schistosomiasis: Resistance to praziquantel and oxamniquine induced in Schistosoma mansoni in mice is drug specific. Am J Trop Med Hyg 51: 83-88.

11. Wang WL, Song LJ, Chen X, Yin XR, Fan WH, et al. (2013) Synthesis and SAR studies of praziquantel derivatives with activity against Schistosoma japonicum. Molecules 18: 9163-9178.

12. Li-Jun S, Huan L, Wen-HF, Gu-Ping W, Xu-Ren Y, et al. (2016) Oxadiazole-2oxides may have other functional targets, in addition to SjTGR, through which they cause mortality in Schistosoma japonicum. Parasit Vectors 9: 26

13. Treger RS CA, Rai G, Maloney DJ, Simeonov A, Jadhav A (2012) Oxadiazole 2-oxides are toxic to the human hookworm, Ancylostoma ceylanicum, howeve 
Citation: C M A Gause M, Wen-Hua F, Li-Jun S, Chuan-Xin Y, Bainian F (2017) Synthesis and SAR Studies of New Oxadiazole-2-oxide Derivatives with Remarkable In Vitro Activity against Schistosoma japonicum. J Microb Biochem Technol 9: 535-543. doi: 10.4172/1948-5948.1000339

glutathione reductase is not the primary target. Int $\mathrm{J}$ Parasitol Drugs Drug Resist 2: 171-177.

14. Darren JG, Allen GR, Yue-Sheng L, Donald PM (2011) Diagnosis and management of schistosomiasis. BMJ 342: d2651.

15. Capron A, Dessaint JP (1985) Effector and regulatory mechanisms in immunity to schistosomes: A heuristic view. Annu Rev Immunol 3: 455-476.

16. Doenhoff M, Utzinger J (2008) Praziquantel: Mechanisms of action, resistance and new derivatives for schistosomiasis. Curr Opin Infect Dis 21: 659-667.

17. Pavlin BI, Kozarsky P, Cetron MS (2012) Acute pulmonary schistosomiasis in travelers: Case report and review of the literature. Travel Med Infect Dis 10: 209-219.

18. Keiser J, Utzinger $\mathrm{J}$ (2012) Antimalarials in the treatment of schistosomiasis. Curr Pharm Des 18: 3531-3538.
19. Hou XY, Gray DJ, Balen J, Luo XS, He YK, et al. (2008) A randomized, doubleblind, placebo-controlled trial of safety and efficacy of combined praziquantel and artemether treatment for acute Schistosomiasis japonica in China. Bull World Health Organ 86: 788-795.

20. Navaratnam AM, Sousa-Figueiredo JC, Stothard JR, Kabatereine NB, Fenwick A, et al. (2012) Efficacy of praziquantel syrup versus crushed praziquantel tablets in the treatment of intestinal schistosomiasis in Ugandan preschoo children, with observation on compliance and safety. Trans R Soc Trop Med Hyg 106: 400-407.

21. Organization WH (2014) Schistosomiasis: Number of people treated in 2012 Wkly Epidemiol Rec 89: 21-28.

22. Gasco A, Sorba G, Di Stilo A, Calvino R (2014) NO donors: Focus on furoxan derivatives. Pure Appl Chem 76: 973-981. 